\title{
FEATURES A HOLISTIC PROCESS OF ADAPTATION OF THE INDIVIDUAL IN SOCIAL SYSTEMS AND INTERNET NETWORK
}

\begin{abstract}
In article it is shown, that the specific character of the whole process of adaptation of the personality in the social systems is not exhausted by the peculiarities of its elements, such as personal maturity, changing the terms of the social environment, and is determined by the interaction of the structural components of the adaptive capacity of the individual. And disadaptation of one of these components affects the integrity of the process of adaptation of the person. Determined that, on the basis of the analysis of the structural components of the adaptation of the personality (adapted social situation, social adaptive need, mental adaptive need) it is necessary to clarify the role of each of these components in the process of its adaptation. According to supporters of cognitive psychology, in the process of interaction with the environment of the person receives the information, which contradicts the existing facilities, while experienced a state of discomfort, which stimulates the search of possibilities of its withdrawal or reduction. To this end, may begin attempts to refute the information received, change your own settings, search for additional information with the aim of establishing coherence between the former views and the other information. In fact, psycho-correction, psychotherapy, training, from the point of view of adaptation and rehabilitation in different social contexts (medical care, education, vocational training and improvement of skills) subject to the common goal of improving the organization of the process of adaptation and rehabilitation of the person in a specific action on the psyche of those or other operating means. This process is carried out at the decision of the resolution of the conflicts, which are experienced subjectively.

Keywords: personality, the adaptation process, adaptive capacity, and the social system, the Internet network.
\end{abstract}

\section{INTRODUCTION}

It is necessary to pay attention to the fact that the concept of the development of personality in Russian and foreign works of the last years is not opposed to adaptation, which is a historical recognition of the integrity and indivisibility of various changes in its self-actualization. During the last decades of research into the development and formation of personality in the process of its interaction with the environment, one way or another connected with the study of the mechanisms to ensure socio-psychological adaptation of the personality to the conditions of activity in which development takes place. Today were productive study of the subjectivity of man, possibilities of its self-promotion and selfconstruction in the context of the theory of human adaptation. In this direction a significant contribution to the study of problems of adaptation of the individual to the

${ }^{1}$ Prof. Nataliya Zavatskaya, Doctor of Psychology, Professor, East Ukrainian National University named after Volodymyr Dahl, Ukraine, tel. +38 06672325 28, e-mail zavadski65@mail.ru 
social environment is the work G. O. Ball, P. V. Kuznecova, S. O. Larionovoi', S. D. Maksymenko, N. Ju. Maksymovoi', A. A. Nalchadzhjana, L. E. Orban-Lembryk, B. D. Parygina, S. T. Posohovoi', T. I. Rongyns'koi' etc. Theoretical provisions laid down in the works of these scholars became the basis of the proposed research project.

If the notion of «the process of social adaptation» reflects the phenomenon of inclusion and integration with the community and self-determination in it, and sociopsychological adaptation of personality consists in the optimal implementation of the internal capacity of the person and his personal capacity in socially important activities, in the ability of preserving itself as a personality, interact with the surrounding society in the specific conditions of existence, the social disadaptation is considered by the majority of researchers as a breach of active adaptation of the individual to the terms of the social environment due to a false or insufficiently developed human notions of themselves and their social networks, inadequate means of communication, lack of communication skills, etc. Researchers (B. M. Almazovym, O. I. Zotovoju, N. Ju. Maksymovoju, L. F. Shestopalovoju etc.) note that the social disadaptation cause disruptions in the process of mastering the personality of the respective roles of the entry in a new social situation, and the acquisition of skills of communication, interaction, and is accompanied by discontent with the personality of its status in the group, the level of its communicative potential, reduced self-esteem, the dilution of the individual.

\section{PURPOSE OF THE RESEARCH}

The theoretical analysis of the problem shows that the social adaptation is a continuous process of integration of the individual in society, the process of adaptation of the individual to the terms of the social environment, as well as the result of this process. The ratio of these components, which determines the character of the behavior, depends on the goals and values of the individual and the ability of their achievements in the social environment. The result is the formation of self-consciousness and the role of conduct, ability to self-control and adequate links with others. The main types of the adaptation process are formed depending on the needs and motivations of the individual: the active type are characterized by a predominance of active influence on the social environment; passive - type is determined by the passive, conformal the adoption of the goals and values of the group.

\section{METHODOLOGY}

The research comprised of an extensive literature review including the study from various books and articles.

\section{FINDINGS}

Note that the concept of social exclusion, as the term «disadaptation», introduced in the science of international scientists is in the 50-ies of XX century. This concept was created by representatives of social medicine and medical sociology (P. Delore, And. Dussert, R. Dubuot, E. Huant). The principal cause of social exclusion they saw as the distortions of the conditions of human life conditions of its formation as a biological species. So, P. Delore defines social exclusion as a condition of the person, which is not found in the environment conditions, which correspond to its needs, abilities and wishes, which may lead to disunity, or conflict with the environment. 
Such views are found in the works of other representatives of the theory of social exclusion. E. Huant and And. Dussert treat diseases in General, as an expression of maladjustment to the environment. In turn maladjustment to the environment is a disease and can be accompanied by such psychopathological manifestations of how aggressive the euphoria and social tensions, as well as the loss of a man of his individuality. In addition to diseases, which, in their opinion, is a consequence of the normal social exclusion, is more disorders through the so-called reverse social exclusion, under which the researchers have in mind not only the adaptation of the human organism to the environment, but also the reverse process - the adaptation of the environment to human life, which further reinforces the exclusion, alienation of the social environment in relation to man and mankind.

We share the opinion A. A. Nalchadzhjana that paradoxical in the concept of E. Huant and I. Dussert is their assertion, that in the settlement of social life neurotic, unstable people with arrhythmic and pathologically tense nervous system feel less severe disorder with the environment, because they themselves are in a state of functional arrhythmia, while a person with a refined perception and rich inner world will suffer from social exclusion. From this it follows that neurotics successfully oppose to social exclusion than healthy people. However, not sharing the similar point of view of representatives of the concept of social exclusion, it is necessary to note, that they are the first made the conclusion about the causes of social exclusion and its consequences in the life of every individual.

Summary of the basic material of research. For the analysis of the Genesis, dynamics of the contents and structure of disadaptation of the personality is expedient, in our opinion, the use of the theoretical model of personality, of the proposed $\mathrm{A}$. V. Petrovs'kym i M. G. Jaroshevs'kym. Genesis desadaptation personality is understood as the formation of the exclusion of the individual for the violations of interaction with the material and social environment in the process of activity, communication, knowledge, that is, as a result of certain strains in the course of ontogenesis and sociogenesis. Understanding the Genesis of exclusion contributes to psychogenetic the concept of individuality, the concept of personality, which is developing the concept of historical and evolutionary approach to the understanding of the individual. Thus, according to the psychogenetics the concept of personality in ontogenesis there is a change of the mechanisms of realization of functions of the organism. Disruption of the normal functioning of these mechanisms can lead to inadequate reactions to internal and external stimuli, to desadaptation manifestations. In the basis of the concept of identity, which develops, lies the idea of formation of the personality in the social environment through adaptation, individualization and integration. According to this concept in the early stages of the development of personality mostly turns out to be adaptive activity. In the future behavior mainly determined by individual psychological characteristics. The result of social exclusion is a condition desadaptation personality. The basis of desadaptation of conduct constitutes the conflict, and under his influence is being gradually formed an inadequate response to conditions and requirements of the environment in the form of those or other aberrant behavior as a reaction to systematically and continuously contributing factors, to cope with that person cannot. This point of view is shared by many psychologists (I. A. Myloslavova, S. T. Posohova, O. G. Soloduhova, A. Fernhem, N. Hodorivs'ka, etc.). The authors determine the deviations in the behavior through the prism of a psychological complex ecological the alienation of the subject and, 
consequently, the absence of the possibility to change the environment, stay where painful for him, aware of his own incompetence lead the subject to the transition to the protective behaviors, creating protective emotional barriers in relations with others, reduction of the level of ambition and self-esteem. In the framework of this approach in the socialpsychological desadaptation is understood as a psychological condition caused by the functioning of the psyche on the verge of its regulatory capacity, which is expressed in the lack of activity of the individual, the difficulty of implementation of the basic social needs (the need for communication, recognition, self-expression), in violation of self-assertion and the free expression of their creative abilities, in an inadequate guidance in situations of dialogue in the distortion of the social status of desadaptation personality.

As noted V. J. S'omke, a high level of rigidity in the structure of personality is a risk factor « desadapted states». Rigidity, which is manifested in the inability to control the program of life of individuals, leads to deformations in the cognitive, affective and motivational spheres. So, cognitive rigidity leads to the exclusion of the individual in connection with its inability to accept the changes taking place in the environment, and adequately react to them. Affective rigidity is expressed in the slow emotional reaction to the events in her fixation on the same objects, the inviolability of the emotional significance of the events that have been changed. Motivational rigidity is the inflexibility of motivation and necessity sphere of the personality, in the impossibility to change the habitual ways of meeting the needs of the changing conditions of life. Especially unfavorable for identity is a complex manifestation of cognitive, affective and motivational rigidity, connected with egocentrism, high self-esteem, narrow interests, stubbornness, etc. On the other hand, excessive flexibility, disinhibition, poor self-control can also lead to exclusion.

Productive for the analysis of the structure of disadaptation is systemic, structurallevel and the structural-functional approach used in the study of activity of the person. The structure of the exclusion of the individual, we make on the basis of different concepts of behavior and motivation of behavior, activities, communication, and cognition. It should be emphasized that the structure of the manifestations of disadaptation personality in specific situations determines the level of involvement in the design of the internal state of the organism, psychological factors, and the intensity of the external factors, genetic and individual experience. As the basic structural elements of exclusion can be seen psychophysiological, psychological and social components. The attraction of those or other units in the structure of exclusion can be explained on the basis of concepts of operational mediation interpersonal (interindividual) relations (A. V. Petrovsky), interindividual representation of the individual in personalization (V. A. Petrovsky). The concept of interindividual representation of personality is the theoretical basis for explaining the decisive significance of the individual-psychological peculiarities of the subject of the intensity and orientation of the manifestation of its desadaptation. Any impact of the environment (material and social, surrounding people) ultimately are refracted through individually-psychological characteristics of the individual and are in the «processed», decorated with personal characteristics the light, in the form of activity, causing changes within the individual and outside it - in behavior, in the process of activity, communication and cognition, or in the form of an instinctive or habitual (based on experience) reaction to a stimulus.

The role of psycho-physiological mechanisms in the formation of disadaptation of the personality is possible to confirm the words of B. M. Teplov that «physiological activity is 
one of the " mediated links, thanks to which naturally-deterministic properties of the nervous system are reflected on a psychological level.»

On the mental level, if we consider the desadaptive behavior as a form of manifestation of the activity of the subject, as the structural elements of its manifestation is possible to identify target, motivational and instrumental basis of activity (V. A. Petrovsky), needs, motives, goals, installation, emotional changes, whole and fragmented mental state.

At the social level, the structural elements of disadaptation are a different kind of deformation in the structure of personality and social and role-playing activity. Structural elements of psycho-physiological and psychological disadaptation are also included in the structure of social exclusion, as one of its components. The functions of social exclusion are in a very wide range of interpersonal relations in the form of aggression, conflicts, in deviant and delinquent behavior. The highest degree of social exclusion, as a rule, leads to a serious and dangerous for surrounding people and society as a whole antisocial behavior. In fact psychological bases of rehabilitation of such persons we were trying to solve in our study.

On psycho-physiological structural components of the activity of the individual (activation or activation, strength and lability), which characterize the neurophysiological characteristics of the nervous system, in those cases the signs of activity in desadaptive behavior they, I think, able to determine the dynamic manifestations of desadaptation in different spheres of life: legal, intellectual, strong-willed, communication. To such conclusion we come on the basis of extrapolation of data on the activity received in psychophysiological research, in cases of manifestation of the activity in a state of desadaptation and in desadaptive human behavior.

This conclusion, in our opinion, is confirmed by the results of researches of the formal-dynamic side of the activity as a system of characteristics of individual behavior that reflects, at least, three separate aspects of it: high speed, which detects the speed of the flow of individual behavioral acts; ergic associated with the inner desire of the individual to the strenuous activity; variation that manifests itself in the tendency to diversity and novelty. Formal-dynamic indices of activity identified in the psychophysiological studies are directly related to the psychophysiological factors. In particular, O. I. Krupnov examined the relationship between motivation and meaningful, effective and dynamic characteristics of human activity in different spheres of activity, the relationship between the dynamic characteristics of the activity and the specific characteristics of human emotion. He found the opposite influence of fear and anger on the dynamic characteristics of the intellectual, motor and strong-willed components of human activities. As you know, the fear is characterized as tense emotional state that is associated with the expectation of a threat. At the same time if the source of the threat remains uncertain or unconscious, a state of anxiety. Anxiety, from the point of view of our study, is considered as a significant structural component of the adaptation of the personality. Describing the anxiety from the point of view of its negative consequences for the individual, researchers define pathological anxiety as non-controlling person, which leads to serious violations of the psyche. In their opinion, there is a certain level of anxiety, essential to ensure that adaptation to the environment, however, high anxiety becomes desadaptive factor.

So, desadaptation the property of the individual and disadaptation of the personality as a phenomenon and state (desadaptation) are formed as a result of violations of the 
adaptation mechanisms of the organism, subject and personality. At the level of the organism exclusion may cause various deviations from the physiological and physical development, as well as pathological violations of the functions of the organism. At the level of the subject of the cause of psychological disadaptation there are violations in the sphere of psychic mechanisms of human life. On a personal level, the reason for the exclusion is the difficulties of adaptation of the subject to social norms of behavior, values, accepted in the society, as a result of the negative life experiences, inadequate mental development. The structure of social disadaptation of the personality should include anxiety and rigidity, discontent affiliation, the desire for power.

Analysis of the dynamics of psychological peculiarities of the personality in the process of adaptation to the changed conditions of life and the influence of psychogenic factors shows that regardless of the intensity of the psycho-emotional loads of change in the structure of the psychological characteristics of mostly negative in nature, and the longer the duration of the psycho-emotional loads and a more intensive influence of psychogenic factors, the more severe consequences for the mental state of the person. In addition, in middle age increases heterochronism and variability of development, which is largely due to the imposition of ontogenetic and biographical lines of development. However, as the researchers note, maturity is the least known period of ontogenesis, which is characterized by a high level of development of the spiritual, intellectual and physical abilities of man. Specificity of the development of the adult person is that she decides not already educational and life goals. Adult always has a certain idea of his own life, which includes events individually-psychological, biological, historical character, which cover the past, present and future. In connection with this most adequately study the development of the personality in adulthood through the analysis of the path of life, personal development and self-development, which becomes especially important in an era of social change and complications, intensification of public life. In the Mature age the activity, as a rule, is directed on integration of the subject with referent groups. The process of integration takes place at intensive operation of reflective activity. Violations of the stages of the development of personality can formdesadaptation. Regarding the dynamics of the content of desadaptation personality and its psycho physiological, psychological and social components, they are also required to ontogenetic changes in the individual and sociogenesis. As shows the theoretical analysis of the dynamics of desadaptation person, in the ontogenetic aspect, developing in the direction of weakening of its manifestations. However, with respect to persons who, before this could not adapt to the social environment, for example, persons with Internet addicted behavior, this question remains acute. The most acute is the problem of adaptation to the social environment of persons who have served a sentence in places of deprivation of liberty. The researchers, who studied this problem, in particular V. L. Vasyl'jev, O. I. Krukovych, S. F. Levin, V. G. Romek, T. R. Tatydynova, V. M. Trubnykov, indicate the typical difficulties of entering of these persons in a new environment. According to N. V. Dmytrijevoi', M. V. Drumovoi', O. M. Jepanchyncevoi', O. G. Karajani, L. O. Kytajeva-Smyka, V. O. Kontorovych, P. A. Korchemnogo, O. G. Maklakova, V. Je. Popova, I. V. Solov'jova, V. V. Stasjuka, S. V. Chermjanina, L. F. Shestopalovoi', Je. B. Shustova, the burden of adjustment in the mature age of peaceful living conditions for experience and participants of combat operations. The lack of control of such persons for their own reactions to the changes taking place in the midst of them, to a certain extent explained by their rigidity, which, in turn, as the property and the condition of the 
individual is one of the most significant factors, which defines the structure of disadaptation of the personality.

Adaptation and reinsertion Express the degree of adjustment of the individual personality's structures and their correction or the degree of restructuring of the personality as a whole. The process of adaptation connected with the correction, completion, deforming, partial restructuring or separate functional systems of the psyche, or the personality as a whole. Re-adaptation concerns the values, goals, norms, semantic entities of the personality and its necessary -motivational sphere, which are reconstructed on the opposite in meaning, ways, and means of implementation. The process of reintegration is bound or with a radical restructuring of the functional systems in General, in the person of the extraordinary circumstances, or with the transition from a state of adaptation in a familiar environment in a state of adaptation in the new conditions, which differ from the pre-conditions of life and activities (for example, in the transition from one civilian conditions in the military, etc.). Reinsertion is the process of transition of a person in the new conditions of life and activities, which are significantly different from those to whom she had adapted. Some researchers regard readaptation as the end result of the process of social rehabilitation of the person. In our opinion, it is the term «reinsertion» precisely reflects the essence of the process for a period of maturity, in contrast, for example, the term «re socialization», which reflects the essence of this process for a period of childhood. Therefore, social readaptation can be defined as the end result of the process of social rehabilitation of the person and the process of re-inclusion of a person in the social context and the formation of her compensatory social skills (after psycho trauma, heavy and long illness, after the forced change of way of life, through which were affected by the social contacts, etc.).

The person as a system-forming quality of a person, as a body of the integration of natural and social figure (B. G. Anan'jev, V. V. Petuhov, V. V. Stolin), as an integral psychological management body of human behavior (V. P. Zinchenko), and its adaptive capacity is, in our opinion, the main instrument of rehabilitation in a situation of crises. However, if the conditions of life of the man of mature age have dramatically changed and it has to adapt to such contradictions and changes, this process is more complicated. A man lost in a critical situation, the return to a normal life and she has to re-adapt to the previously usual terms. It turns out that life is divided into «before» and «after», and often return to the previous himself is not possible, and the influence of the critical situation is much stronger than the demands of daily life. The person remains under the authority of the «ultimate» experience, because nothing in the ordinary life cannot be compared with him on the intensity of the emotion. Moreover, the impact of negative emotions, as a rule, stronger. It is a crisis experience becomes a source of exciting memories, dreams, and experiences. It is voluntary or involuntary treatment is too painful, and the person by all means wants to avoid it, which further complicates the process of liberation. In principle, faced with the influence, which is the threshold for a «normal» sensitivity, the man produces a kind of defense mechanism, ceasing to respond to most of the stimulation. Therefore, many of the survivors in the recent time the situation, talking about his indifference, apathy (although sometimes this is accompanied by a motivated or unmotivated explosions of anger or aggression). The indifference and insensitivity applies, first of all, to the events of the life, then how experienced the tragic experience of the remains emotionally meaningful and relevant, and the possibility of social rehabilitation of such persons is very limited. 
Under socially adapted situation most often mean a relatively new and unusual for the person status of a social environment, which requires a certain restructuring of its behavior, change the previous forms and ways of life. The social need is the main motive force in the formation and development of social activity of the individual, its aims activities and rehabilitation. Prerequisite for rehabilitation may occur in such a contradiction: the person needs to deploy its social values, orientation, installation, etc. to the social situation and through this need can be adapted to a particular situation; the particular social situation does not create opportunities to meet the needs of the individual, and therefore, its social activity is directed on the change of the situation in accordance with their needs. This has implications not only for the theory, but also for the practice of management of the process of social rehabilitation, which, in our opinion, implies the necessity of purposeful construction of such a micro social environment, which would encourage the formation of the human certain social qualities, contributing to its reintegration in a wide micro social environment; personal development; the possibility of self-realization; development of a dynamic model of rehabilitation of the person, taking into account these components and the requirements of the wider social environment.

Considering the mechanisms of adaptive reactions of the person in response to environmental factors, and providing psychological reaction to the impact of the social environment, it is expedient to introduce the factor of social reintegration, the опосредствующее operation of this mechanism - the adaptive capacity of a person as well as the aggregate value-semantic and motivational formations and operational characteristics of ways to implement the face of their motives. In a crisis situation, this factor becomes the master, and the level of social rehabilitation of the directly connected with the level of development of the adaptation potential of a personality. In respect of middle-aged adults, who have experienced stressful situations (served their sentence in places of deprivation of liberty, the veterans, military servicemen, transferred to reserve or retired persons dependent on psychoactive substances), we have the assumption that the figures on the components of their adaptive capacity reduced. So, in motivationalnecessary the sphere of persons we assume violations of value orientations and focus of motivation in the sphere of self-consciousness of the people the possible inadequacy of self-appraisal, low level of reflection, the ineffectiveness of psychological defense mechanisms; in the emotional-volitional sphere of the lack of voluntary self-control; among individually-typological peculiarities of - disharmonious combination of accented character traits. Social disadaptation of the studied population, in our opinion, is due to their low adaptive capacity.

\section{CONCLUSION}

So, in spite of the fact that the concept of «adaptation» is applied for a long time, unambiguous interpretation is not found, that is explained, first of all, a variety of spheres of its use. The socio-psychological level of the adaptation process is two-fold: on the one hand, it implies the change of social functions, which are necessary in order to satisfy the requirements of the social environment; on the other - is changing and the environment. In the context of the study under the whole process of social adaptation of personality in the social systems, understand the mutual active adaptation of the individual and the social environment to each other with a view to creating a harmonious interaction for the efficient functioning of the individual in the social systems. Disruption of this process or the implementation of its social disapproval or asocial ways leads to a disruption of the 
whole process of adaptation or leakage, it unacceptable for the society forms. Social disadaptation of leads to disruption of the process of socialization, which is expressed in the complication of assimilation and application of social roles, values, and attitudes. In accordance social work should be aimed at replacement of the anti-social norms, values, and attitudes on prosocial. This process we treat as a social resettlement - purposefully organized by the restructuring of the moral values and behavioral spheres of personality, which contributes to the formation of socially-valuable orientations and behavior. The complete process of social adaptation of personality in social systems can be provided with the knowledge and reflection of changes of the environment; activity of the individual in the regulation of adaptive capacity; the transformation of the adaptive capacity of a more complex and advanced forms of interaction with the surrounding reality.

\section{BIBLIOGRAPHY}

[1] Ball, G.A., Phenomenon of choice in the context of social behavior, Social psychology 2005, G.A. Ball, № 1(9).

[2] Kaps'ka, A. J., Socialization - the most important task of social and educational work, A. J. Kaps'ka // Visnyk ChDPU im. T. G. Shevchenka. - Series: Psychological Sciences 2006, T. 1, issue. 41.

[3] Karamushka, L. M., Management Psychology, L.M. Karamushka. - K.: Millennium 2003.

[4] Maksimenko, S.D., Genesis of the existence of the individual / S.D. Maksimenko, K.: CMM 2006, 236p.

[5] Maximova, N.Y., Psychology of addictive behavior, N.Y. Maximov. - K. CUP "Kyiv University" 2002.

[6] Nalchajyan, A.A., Psychological adaptation: mechanisms and strategies, A.A. Nalchajyan. - [2nd ed., Rev. and add.]. - Moscow: Penguin Book 2002.

[7] Orban-Lembryk, L.E., Social transformation and the problem of socialization mature man, L.E. Orban-Lembryk, Problems of Society. and ped. Psychology. : Proc. Science. Works of the Institute of Psychology. them. Academy of Pedagogical Sciences of Ukraine, Ed. S.D. Maksymenko 2006, T. VIII. issue. 2.

\section{CECHY HOLISTYCZNEGO PROCESU ADAPTACJI JEDNOSTKI DO SYSTEMÓW SPOŁECZNYCH ORAZ INTERNETU}

W artykule ukazano, że specyfika procesu adaptacji osobowości w systemach społecznych nie wyczerpuje cech jej elementów, takich jak osobista dojrzałość, zmiana warunków środowiska społecznego i określa interakcję składników strukturalnych adaptacji potencjału osobowości. Brak możliwości adaptacyjnych jednego z tych elementów wpływa na integralność procesu adaptacji człowieka. Ustalono, że na podstawie analizy składników strukturalnych adaptacji osobowości (dostosowanie pozycji społecznej, adaptacja do nowego środowiska społecznego, adaptacyjna potrzeba psychiczna) należy wyjaśnić rolę każdego z tych składników w procesie jego adaptacji. W procesie interakcji ze światem człowiek otrzymuje informacje, które są sprzeczne $\mathrm{z}$ istniejącymi obiektami i istnieje możliwość badania stanu dyskomfortu, który stymuluje poszukiwanie możliwości jego wycofania lub zmniejszenia. W tym celu można próbować obalić te informacje, zmienić swoje ustawienia, wyszukiwanie informacji w celu ustalenia spójności między dawnymi 
poglądami i innymi informacjami. W rzeczywistości, psychokorekcja, psychoterapia, szkolenia, z punktu widzenia adaptacji i rehabilitacji w różnych społecznych kontekstach (opieka medyczna, edukacja, szkolenie zawodowe i podnoszenie kwalifikacji), zgodnie z ogólnym celem doskonalenia organizacji procesu adaptacji i rehabilitacji człowieka, maja określony wpływ na psychikę tych lub innych działających środków. Proces ten odbywa się na podstawie decyzji rozwiązywania konfliktów, które doświadczane są subiektywnie.

Słowa kluczowe: osobowość, proces adaptacji, adaptacyjny potencjał i społeczne systemy, sieci, internet.

DOI:10.7862/rz.2015.hss.57

Przesłano do redakcji: październik 2015

Przyjęto do druku: grudzień 2015 